\section{B A Institute of \\ YK Business Administration \\ TK \\ Karachi \\ Leadership and Ideas for Tomorrow}

Business Review

Volume 5 Issue 2 July-December 2010

$7-1-2010$

\title{
Paradigmatic asymmetries between economics and management discourses as instrumentalities of Capitalist order
}

Javed Akbar Ansari

Institute of Business Management Karachi, Pakistan

Zahid Siddique Mughal

National University FAST-Business School, Karachi

Follow this and additional works at: https://ir.iba.edu.pk/businessreview

Part of the Business Administration, Management, and Operations Commons, and the Economics Commons

\section{(c) (1)}

This work is licensed under a Creative Commons Attribution 4.0 International License.

\section{Recommended Citation}

Ansari, J. A., \& Mughal, Z. S. (2010). Paradigmatic asymmetries between economics and management discourses as instrumentalities of Capitalist order. Business Review, 5(2), 91-110. Retrieved from https://doi.org/10.54784/1990-6587.1246

This article is brought to you by iRepository for open access under the Creative Commons Attribution 4.0 License and is available at https://ir.iba.edu.pk/businessreview/vol5/iss2/6. For more information, please contact irepository@iba.edu.pk. 


\title{
ARTICLE
}

\section{PARADIGMATIC ASYMMETRIES BETWEEN ECONOMICS AND MANAGEMENT DISCOURSES AS INSTRUMENTALITIES OF CAPITALIST ORDER}

\author{
Javed Akbar Ansari \\ Institute of Business Management Karachi, Pakistan \\ Zahid Siddique Mughal \\ National University FAST-Business School, Karachi
}

\begin{abstract}
This paper contrasts the economics and the management discourse paradigms to identify the purposes these discourses serve in sustaining and reproducing capitalist order. The paper begins with an identification of the major characteristics of capitalist order. Section 2 and 3 compare and contrast economics and management discourses respectively on the basis of the role they are designed to play in legitimizing and operationalizing capitalist order. The concluding section argues that their roles vary in efficacy. Both economics and management provide incomplete justificatory and reformative proposals but this is because capitalism is an inherently conflictive social order always threatened by implosion. Economics and management discourse have often evolved in respect to capitalist systematic crises.
\end{abstract}

Key Words: Economics, Managerial Theories, Capitalism, Justice, Legitimacy

\section{CAPITALIST ORDER}

Capitalism emerged in the early modern period in the Mediterranean city-states. It developed into a national and imperial system in 19th century Britain - the seat of the world's first industrial revolution was also the first capitalist world power. Capitalist global dominance was seriously challenged by USSR and China during 1917-1991 [Hobsbawn (1995)] but from then on capitalism is said to have entered a globalizing phase after the collapse of the Soviet Union and the (partial) adaptation of capitalist transactional forms by China. However, it is sometimes argued that globalization has already entered a phase of disintegration [Gray (1999)].

Capitalism's historical evolution has taken several forms - there exist and have existed several different capitalist systems. But capitalism is a 'relentless totalizer' [Meszoros (1995)], a whole, a system, and not merely a 'life world'. It does not fit into another system - there is no such thing as Christian capitalism, Islamic capitalism, Confucian capitalism etc. Capitalism subsumes the social order from which it emerges and creates its own social order-its own individuality, its own society and its own state. It is important to distinguish what is constant and what varies in the capitalist life system. 
We must identify what is common between Japanese and American capitalism (why it is justified to describe both systems as capitalist) as well as what separates and distinguishes them from each other.

Defining these common features requires a working definition of capitalism. Above all capitalist order is founded on the general acceptance of a world view with the following characteristics:

Individuals act rationally when they seek to achieve ends that they freely set themselves

- Each individual has an equal right to autonomously determine his own endshis conception of the good

- The purpose of social organization is to ensure:

- that individuals become capable of un-coercively determining their own conception of the good

- that society organizes human relationships in a manner, which enables all individuals to acquire a continuously increasing flow of resources for fulfilling these autonomously conceived life plans

- Political power has to be structured through law and administration in such a manner that the set of social relationships required for the promotion of individual liberty and capital accumulation are strengthened and reproduced continuously [Ansari and Arshad, (2006), chap 2].

Capitalism thus requires the continuous reproduction of capitalist individuality, capitalist society and capitalist state structures. There is an organic interconnection between capitalist individuality, capitalist social organization and capitalist governance. Capitalism is correctly viewed as a totality because of this inter-connection. Thus the capitalist market - the main form of social organization within capitalist society - cannot function in the absence of capitalist individuality. If men seek the pleasure of Godas Saint Francis of Assisi and Imam Ghazali (RA) expect them to do- they will not act as utility and profit-maximizers and the laws of supply and demand will cease to be operative (this is recognized by both Weber (1966) and Tawney (1949). If law does not recognize corporate personhood and interest and speculation based transactions as legitimate, unlimited accumulation cannot take place. Capitalism is a system in the specific sense that its three component sub-systems - individuality, society and stateare inter-connected and inter-dependent, each sub-system requires the continuous reproduction of the other sub-systems for its own survival.

Norms and values of capitalism distinguish it generically from other systems. The essential capitalist value is freedom; that is why capitalism is often described as a 
'free society'. The individual in capitalist society is committed to freedom. Freedom is self determination - the right to do what one pleases, as long as this does not interfere with the right of all other members of society to do as they please. Capitalism recognizes no criteria for evaluating the worth of personal choices. The only unworthy act is to restrict the freedom of the individual to do as he pleases.

Capitalism recognizes the 'shortage of material resources' as the most important constraint on freedom. Society must be organized to maximize the potential for producing and consuming goods and services (for an increase in goods and services is a prerequisite for increasing freedom). My ability to do as I please in capitalist society is ultimately limited by the size of my income and wealth. Therefore two very important values promoted by capitalism are acquisitiveness and competition. I must be induced to desire more and more resources for myself. Moreover, since everyone in capitalist society possesses this insatiable desire for more resources they must compete against each other and derive pleasure from this competition. Acquisitiveness and competition are thus necessary means for continuous increase in resources. This continuous increase in resources available for production and consumption becomes an end in itself in capitalist society. A capitalist society is one which accumulates for the sake of accumulation and evaluates (assigns value to) all activities in terms of their contribution to accumulation.

There is of course nothing natural or inevitable about regarding acquisitiveness and competition as individual or social norms [Tawney (1949): p. 17-24]. Christian terms for acquisitiveness and competition were avarice and covetousness respectively. The Christian social system had sought to promote virtues of poverty and charity while avarice and covetousness were classified as sins. For over a thousand years the European economy was embedded in social practices which ought to promote these Christian values. As Weber (1966) and Tawney (1949) have shown it was the rejection of these values which led to the emergence of capitalism. Similarly, a rejection of the values of acquisitiveness and competition will lead to the overthrow of capitalism.

This shows that contrary to the claims of neo and new classical economists [e.g. Hayek (1998)] capitalism has a history. Capitalist markets invariably emerge from non-capitalist social formations. In the twenty first century legislative and policy-making measures adopted by the World Trade Organization seek to construct technology markets by universalizing the US patent system. There is nothing spontaneous, automatic or natural about the processes of legitimization which reduce the access of developing countries to the new technologies. Capitalist markets and capitalist property forms are historical constructions in the specific sense that laws and practices are required for their emergence and sustenance. Historically constructed markets cannot be viewed as natural outcomes of myriad unrelated events or attributed to the natural evolution of technology. This illustrates the fact that capitalism requires regulation. The politically legitimated source of this regulation has traditionally been the liberal and/or nationalist state and its agencies; but regulation is also undertaken by firms, state and its agencies 
such as the IMF and the WTO [Ansari and Khan (1998)]. Regulatory systems have their origin in national and local histories and the form and intensity of regulations continue to change over time. This brings us to the important point that capitalism exists in several national versions [Gray (1999)] and the history and customs prevalent in a country determine both the pattern of capitalist regulation and the structuring of capitalist transactions. Regulation of capitalist order is required for legitimating capitalist property; the vestment of control of this property in the hands of technically skilled managerial elite (who are not the formal owners of the assets they manage); the enforcement of capitalist contracts premised upon the formal equality and the factual inequality of contractees, etc. Although it is the duty of every capitalist state (be it American, Pakistani, Saudi Arabian etc.) to preserve these essential elements of the capitalist system, yet each state has to define the scope of capitalist property, the balance of powers between capitalist owners and managers, the legal form of capitalist contracts etc. on the basis of its own history and traditions.

It is thus useful to speak of a 'mode of regulation' (which a set of mediations in a capitalist civil society and state) undertaken to ensure that social distortions created by a specific ordering of capitalist transactions do not destroy the overall political, social and economic coherence of that civil society and state [Aglietta (2000)]. Specifically, these mediations must ensure:

(a) systemic dominance of the desire to accumulate through the promotion of the values of acquisitiveness and competition

(b) continued expectation of increased access to resources for accumulation

(c) ensuring of compatibility between claims and obligations for continuing accumulation

'Post Fordist' order is characterized by growing full time unemployment, increased mal-distribution of income, the spread of consumerism to many developing economies, the growth of part time employment, cheapening of the cost of financial transfer processes across national frontiers, widening of differentials in inter-sectoral productivity growth rates and changes in demographic structures.

Effective mediation processes are required for sustaining "Post Fordism"-it is not a self-sustaining order. Fordist mediation structures are collapsing. Mediation within the work process continues with collective bargaining being replaced by human resource management. As monopolistic competition increases organizational changes in firms and state bureaucratic decision-making structures facilitate outsourcing, automation and the growth of "flexible specialization". All these are mediated, not spontaneous, responses. Creating compatibility between the accumulation regime and the social commitment to capital's hegemony requires the legitimating of these new organizational structures [Boltanski and Chiapello (2008)]. 


\section{Economics and Capitalist Order}

Capitalist transactions require:

- the existence of markets in which anonymous individuals contract for the achievement of personal gratification

- the separation of ownership from control and the vestment of management authority in the hands of a beaurocratic elite which possess technical proficiency in sustaining efficient accumulation

- The universalization of the wage form

- The establishment of the social dominance of the financial markets which

a) facilitate the pursuit of unlimited accumulation through the conversion of money into capitalist money and finance

b) assign relative value to all economic activities in terms of the contribution of each activity to efficient accumulation

Economics is fundamentally concerned with the justification of the pursuit of wealth rather than virtue [Callinicos (1999), chap 1]. According to Smith a society dominated by "a passion for money making" is likely to be a peaceful society — one that avoids wars and internal violence. In an ultimate sense, freedom is identified with the promotion of self-interest.

Justifying transition from religious to civil society - i.e. capitalist order — was a central theme of Adam smith's Theory of Moral Sentiments. Establishing the justification of capitalist order has remained a central theme of all economic schools and political economy discourse since the eighteenth century. In religious (non capitalist) societies, maximization of profit (shareholder's value) does not justify economic activity. On the other hand, economics is concerned to justify the pattern of resource allocation determined by the principle of profit maximization. The best known defense of the profit maximization principle from Smith to Acton is on naturalist grounds [Schumpeter (1949): p. 376-7]. Everyone, it is argued, naturally seeks to possess more than he has and profit maximization is merely a manifestation of this natural avarice. But even if avarice is natural the question remains whether it should be restrained - as sloth is - or encouraged. Smith was conscious of the need to justify avarice and he did so, on the grounds of the famous "invisible hand" argument, which states that when the individual pursues his own profit he contributes to the maximization of social well being. Smith recognizes that maximization of profit by individual corporations may inhibit the maximization of total social profit (welfare) but he argued that the perfectly competitive market was an agent of capital in general and these markets subject individual corporations to a discipline which eliminate the possibility of maximizing individual firms' profit at the expense of total welfare [Smith (1972): p. 341-3]. 
The need to justify capitalist order led the classical economists (Smith, Ricardo, Malthus etc.) to analyze variations in aggregate output and its distribution. The basic unit in their analysis was not the asocial self-determining individual but social classeslandlords, merchants, laborers. The classical economists were profoundly concerned with questions of political philosophy and their focus on distributional areas reflects their attempts to advance claims for the universal validity of the capitalist conception of justice. The need to justify capitalist order has meant that economics is eventually a moral and a normative social discourse. Economics requires every man to accept capital accumulation as the only legitimate social end in itself. The representative consumer and producer (for example the modern representative agent in macroeconomics) is a representative of capital. If a person rejects capital accumulations as an end in itself economics can say nothing to him or about him. All economic schools of thought recognize however that capitalist justice cannot emerge spontaneously even if everybody is persuaded to become a compulsive utility / profit maximizer. This recognition is explicitly reflected in orthodox and post Keynesianism which build upon the insight that supply does not create its own demand and under consumption and overproduction are systematic tendencies nurturing capitalist crises. Keynes stressed the non neutral character of capitalist money, the role of expectations in determining investment decisions and cyclical behavior of aggregate demand and supply. In Keynesian discourse the capitalist state - and not the market — was the primary agency of capital in general and it was the responsibility of the state to ensure capitalist justice through generating full employment equilibrium and steady state growth [Keynes (1936)]. Capitalist justice requires the state to articulate countercyclical fiscal and monetary policies and determine wages through collective bargaining in the labor market. The capitalist state must ensure high and rising wages, low interest rates, state controlled exchange rates and orderly intersectional capital mobility.

Orthodox Keynesianism - the Hicksian interpretation of the General Theory within the IS-LM framework (ignoring uncertainty, expectations, liquidity preferences, arbitrary determination of asset values by financial markets and non neutrality of money) - recognized capitalist market outcomes as producing under full-employment equilibrium. But Hicks disagreed with Keynes about the level and not about the form of state intervention required to generate full employment equilibrium. Hicks accepted the idea that both money supply and public expenditure were exogenous variables under the capitalist state's control. He accepted that the state should manipulate these variables to produce full employment equilibrium. The capitalist state was the agency that concatenated the decisions of individually rational producers, consumers and financers to ensure maximization of total utility / profit [Hicks (1956)].

Orthodox Keynesianism was discredited during the 1972 to 2005 period due first to break down of the Phillips curve and secondly due to the Dot Com financial derivatives boom. Economics responded to this new structuring of capitalist order by formalizing two new discursive paradigms. On the one hand representative agent 
macroeconomics rejected the need for capitalist order justification (there is no alternative) and instead emphasized the second major function of economics discourse- evaluation. We will return to an analysis of 'representative agent' macroeconomics later on this section [Fudenberg (2006)]. On the other hand post Keynesianism (which we equate with radical post-Keynesians) sought to take account of the systematic changes that had taken place since the collapse of the Breton Woods system - accelerated financialization of the economy, persistent unemployment, globalization and the decentralization of the labor process. In the post Keynesian view the capitalist economy has changed so drastically that it requires justification discourses regarding; e.g. monopolistic pricing and output decisions, the need to regulate speculation, dominated financial markets and an analysis of firm behavior, taking account of decreasing costs, increased scale and the need to preserve capacity. The post Keynesians continue to see the capitalist state as the legitimate representative of capital in general and propose policies to enable it to generate just capitalist market outcomes; in essence they provide an analytical framework for justifying social democratic policies [Lavoie (1994)].

Critics of market capitalism such as Sraffa and Marx are also legitimate representatives of the political economy school established by Smith and the Physiocrats. Sraffa's analysis [(1926), (1960)] presents market capitalism as a profoundly unjust system (in the sense that it necessarily fails to maximize profit/utility). Sraffa showed that it was impossible to derive individual or aggregate supply curves and therefore capitalist markets are not likely to yield unique (just) equilibrium price-output configurations. Sraffa also showed that productivity of capital does not determine profits. The pattern of income distribution / resource allocation generated by capitalist markets does not represent any technical imperative for maximizing efficient or equitable utilization of resources. On the contrary, it reflects the distribution of power within a particular capitalist order - i.e. the profit / wage ratio is determined by the struggle for power between capitalist and worker. Therefore market capitalism is not a rational system. The ends it sets itself cannot be realized by the universal practice of its own rationale.

Despite all this Sraffa's original motivation in his 1926 paper was to make microeconomic analysis more useful for understanding capitalist order. He sought a revival of the theory of the firm to take account of credit growth (what we now call financialization) and of the necessary resort of marketing, non-homogenous products to non-homogenous markets. Thus there is nothing in Sraffa rejecting capitalist values, structures and transaction forms. Sraffian suggestions for reforming market capitalism are much more limited than those of the Keynesians - they are mostly focused on the legitimization of monopoly in both product and factor markets [Bhardawaj K (et el) (1990)].

Marx like Sraffa is a critic of market capitalism - not of capitalist order. He sees the capitalist market as an instrument for the realization of surplus value (which accumulates in production) and its expropriation by those who own the means of 
production. To him, market capitalism is unjust not because it extracts surplus value rather because surplus value is expropriated by those who do not produce it. If the expropriators are expropriated, capitalist order will generate just outcomes. Capitalist (accumulation based) order can be justified if means of production are nationalized / socialized and allocation of resources is determined by state planning [Bose (1980)]. Since Marx endorses the fundamental capitalist value - freedom - it has proved easy to re-legitimate capitalist structures and transactions from within the context of the Marxist paradigm [Wilde (1989)]. After all the "end in itself" in non-market capitalist states - the USSR, China, Cuba, Yugoslavia - has always been capital accumulation, an indispensable pre-requisite for the extension of freedom. Von Mises showed nearly a century ago the price/output configurations generated by a perfectly competitive market system are identical to the price/output configurations generated by a system of perfect planning. The leading Marxist economics school today-Analytical Marxism-endorses this finding [Freeman and Carchedi (1996), Mahun (1994)].

Some other recent trends in economics, such as behavioral economics, redesign neoclassical theory by building the observed basis into the behavior of the individual. Behavioral economics thus 'add on (new variables) to standard neoclassical analysis and contributes to the effectiveness of policies designed to move actually existing capitalist individuality towards the idealized capitalist individuality [Fudenberg (2006)].'

\section{HOW DOES MANAGEMENT SERVE CAPITALIST ORDER?}

Section 2 attempted to show that economics discourse has the following main purposes:

1. To justify capitalist norms, regulatory procedures and transaction forms

2. To develop ideal types ("models") against which the behavior of actually existing individuals, societies and states can be evaluated

3. To develop policies which can induce and force individuals, institutions and governments to adopt capitalist norms, behavioral patterns and regulatory procedures

Microeconomics is principally concerned with the first two objectives. It justifies capitalist market order by positing that it provides a value-neutral analytical "tool-box" which can be utilized to achieve the optimal allocation of resources. It shows that society functions equitably and efficiently (both terms defined on the basis of capitalist epistemology) when people are fully (capitalistically) rational. These models of perfectly rational behavior provide a basis for assessing price and output determination processes within both product and factor markets. They show how consumers, producers and regulators ought to behave so that capitalistically optimal resource allocation can be achieved and sustained.

Microeconomics is however weak as far as its policy prescriptions are concerned. It subscribes to Smith's "invisible hand" and Menger-Hayek's "spontaneity" doctrines. 
Once capitalist property rights are enforced ('law and order' ensured says Smith) capitalist markets will spontaneously, unintentionally, necessarily and continuously generate optimal equilibrium (harmonious \& reinforcing) outcomes. Even the intuitionalists and evolutionalists recognize this as a naïve and simplistic model of actually existing capitalism. People do not normally behave as capitalism requires that 'they ought to' [Epstien and Stanly (1989)].

In fact, the key capitalist institution is not the market but the corporation. Markets exist in non-capitalist societies; corporations, on the other hand, are peculiar to capitalism (as is finance). It was capitalism that created the corporation. The corporation is the legal person totally dedicated to the maximization of the shareholders' value. Corporations can exist only within capitalist order, for the maximization of (surplus) value - accumulation as an end in itself — has never been recognized as a raison d'etre of any non capitalist society through out history. Corporations are the quintessential form of capitalist property. It is only when corporations achieve hegemony within a marker that it becomes a capitalist market. If corporations do not exist or are subordinated to non-capitalist property forms the market is not a capitalist market. Like our sabzi mandi, it remains a socially embedded bazaar whose output and price configurations do not reflect a quest for continuously higher levels of capital accumulation.

Management discourse appeared more than a hundred years after Classical Political Economy which was born in the mid to late eighteenth Century - through the writings of Quesmay, Turgot, Hume and Smith. Modern economics-Neo Classical Economics - was well on its way towards becoming the dominant social science paradigm when Management theory was first formalized. Growth of its intellectual predominance restricted the scope for Marginalist discourse. Within European universities neo-classical economics emerged specially in two majors streams; i.e. in the British school (Jevons, Edgeworth, Marshal) and the Austrian school (Menger, Bohm-Bark, Weizer). Both argued that capitalism and all its institutions, money, division of labor and production functions, emerged spontaneously when men behaved rationally. Operation of the "invisible hand" ensured that a system of general equilibrium prices prevailed throughout the system [Schumpeter (1949): p. 411-429]. We are in the best of all possible worlds and capitalism is a uniquely just, optimally efficient life-world which could not be improved upon by management or any form of policy intervention. Efficiently operating capitalist order eliminated the need for Management (both theory and practice).

However, the neoclassical claim for policy irrelevance was severely challenged at the turn of the century by several developments within capitalist order. From the 1880 s onwards, several European countries were shaken by major strike waves led by the new unions which were successful in organizing large masses of non craft workers. In the first decade of the twentieth century, British global hegemony was effectively disputed by emerging protectionist and nationalist regimes in Germany, Japan and America. The Great War (1914-1918) followed and the disintegrating international 
finance and international trade system collapsed comprehensively during the inter-war period (1919-1939). With efforts to restore the gold standard proving futile, beggar thy neighbor protectionist policies and conservative fiscal and monetary stances (based on Neo Classical Economics teaching) led to catastrophic stock market crashes and ushered in the great depression of 1929.

Macroeconomics emerged from the debris of the Great Depression. It refuted the microeconomics doctrine of necessary 'policy irrelevance' and argued that the capitalist state must both govern and intervene in the markets through:

a) A cheap money policy

b) A deficit financing based fiscal policy

c) A capital movement restructionist fiscal exchange rate policy

The twentieth century also saw the emergence of the giant corporation and the consequent discrediting of the model of perfectly competitive markets based on atomisticsmall firms (so central to neoclassical economics discourses). Imperfectly competitive markets theory emerged in Britain and in America and the theories of 'finance capital' and 'monopoly capitalism' were initially formulated by Rudolf Helferding (1969) and Baran and Sweezy (1953) during this period. These theories recognized that market governance and planning was also undertaken by giant corporations. Sraffa also recognized this as early as 1926 .

It is the science of Management and not Economics which focuses theoretical attention on how decisions are made within the corporation and among corporations. Since these are extra market prior decisions - decisions a corporation takes before it enters the market - microeconomics has almost nothing to say about them. It calls the corporation a "firm" and in most microeconomics analysis a firm is treated as a mysterious closed "black box".

Management is specific to capitalist order. Management subsumes administration as the market subsumes the bazaar and the corporation subsumes private property in capitalist order. For example, Management is unknown in Islamic history before the imperialist conquest. Muslims built and rebuilt the Kaaba over several centuries, organized trade spanning three continents, developed an all-Asia transport and communications network, undertook incessant Jihad for almost a thousand and four hundred years all without any study and practice of Management.

Management does not exist in non-capitalistic society because management is dedicated to deploying resources to produce continuously maximized surplus value. The cooperation turns private property into a legal fiction - the share holder "owns" the corporation just as much as a citizen of the ex-USSR "owned" the Socialist Republic and "participated" in the exercise of the dictatorship of the proletariat. This devaluation 
of private property leads to the transfer of control of the resources of the corporation from its legal (fictional) owner to those trained to use these resources to maximize and realize the surplus, the corporation's raisin d, etre. Managers monopolize the type of knowledge on the basis of which resources are used solely for the purpose of continuing, never ending increase in their quantity (capital accumulation).

Capitalism's central value is freedom. Capitalistic individuality is nurtured not through repression but through freedom. Promoting freedom requires that 'preference for preference itself' (capital accumulation as an end itself) be prioritized over all specific preferences. A famous French philosopher of the twentieth century Michael Foucault said that capitalism requires a delicate balancing of "unity" and "diversity"[ Foucault (1988)] . Simply put, this means that every capitalistic individual must:

a) dedicate his life principally to accumulation (that Foucault calls 'unity')

b) be willing to explore varied ways through which accumulation is achieved and accelerated (that he calls 'diversity')

Capitalist order has a unifying purpose - the maximization of utility/profit/rate of accumulation - but seeks the achievements of this purpose through an ever expanding diversity of thought and acts. Management, particularity self and self discipline, are crucial in capitalist order because it is through management that diversity of thought and action is organized in a manner which sustains continuing accumulation as the raison d'etre for individual being and social life.

This purpose becomes evident when we examine management theory. Management theory is an American project. It appeared as an academic discipline in the universities of Pennsylvania and Chicago in the late nineteenth century. Management is a multidisciplinary theory par excellence. It combines themes from psychology, sociology, cultural anthropology, philosophy, political science, economics, mathematics and statistics.

A first attempt to provide a coherent theoretical framework for the study of management was developed in Henry Fayol's theory of universal management process [Fayol (1949)]. He argued that management consisted of the performance of five basic functions (a) planning (b) organizing (c) commanding (d) coordinating and (e) controlling the managed. Management in Fayel's view is a process which begins with planning and culminates in controlling the managed. The purpose of undertaking all these functions is the achievement of 'efficiency', defined in all management literature as the production of greater output value with lower input cost. Fayel saw management as an orderly and rational process, and Fredrick Taylor - the inventor of scientific management-built upon this view. This approach focused upon improving quality, cutting costs and systematizing work processes [Taylor (1947)]. 
Taylor sought to create "a mental revolution" in both managers and workers so that they saw each other as allies and not as antagonists. Taylor's concern was to derive "best practice" operational standards through systematic observational experimentation and analysis of various aspects of the work process. On the basis of extensive time and task studies, Taylor made recommendations about work process recognition of employee selection and training and worker remuneration systems. He saw the capitalist worker as being primarily motivated by high wages and developed a complex remuneration system which links productivity and wage growth. Taylorist methods often proved very effective in raising productivity and reducing cost at the plant level. Work motion study was developed into something like an exact science by Taylor's followers. Attempts were made by them to combine production and cost control techniques and this led to the evolution of a more complex view of worker motivation. Joseph Jaran (1993) taught that management ought to view the worker as an "internal customer". The worker was to be motivated through teamwork, partnership, problem solving and brainstorming. Other "stakeholders, especially those within the corporation supply chain, could also be motivated through the use of these methods. The emphasis on quality management emerged from these insights. Feigenbaum (1951) showed that ultimately it was the customer who determined quality - quality was therefore a subjective, not an objective factor and managing customer preference was the key to quality improvement. Operations management showed how important this was in purchase, inventory management product and service design and design of the work flow process and data processing and communication [Littler (1983): p. 146-151].

This concern with worker, supplier and customer perception facilitated the emergence of the Human Relations Management school [Mayo (1993)]. In this view successful management requires that a manager be capable of working effectively with people of diverse background, perceptions and motivations. The manager must be capable of fusing this diversity into the singularity of accelerated capital accumulation (efficiency and productivity growth). HRM instructs managers to be particularly sensitive to employee diversity.

Human Resource Management (HRM) is an explicit response to the growth of unionization in America. It emerged as a reaction to the 1935 Wagner Act which recognized the unions' right to collective bargaining. HRM preaches that satisfied workers are less likely to join unions. Productivity could be enhanced by changing the attitude of the workers towards each other and towards management. HRM researchers tried to show that emotional factors are more important determinants of productivity growth than physical aspects such as lighting, job description, formal organizational communication systems etc. Management should consciously foster worker empowerment at work. Mary Follett, a pioneering HRM philosopher, urged managers to motivate workers. The boundary separating "management" from "operative" has become ambiguous. Both work for capital, and Follett argued that the worker could be taught to become "an organization man". He could be taught to practice self management (self control) and 
shed his traditional adversarial identity. He could be convinced that productivity growth, efficiency enhancement, profit maximization was necessary for his own well being. People are the key to productivity growth. Technology, standards and work rules do not guarantee productivity growth. Instead, profit growth depends on skilled and motivated workers committed to capitalist norms - utility/profit maximization as an ultimate end in itself [Metcalf and Ururick (1942)].

The complexity of capitalist order reflected in its dialectical pursuit of unity through diversity has been appreciated by authors who seek to address management on the basis of a systems approach [Kass (2003)] . They view the corporation as a cooperative system dedicated to the pursuit of a common end-productivity, efficiency and profitability maximization. Communication is the necessary means for linking the individual workers' motivation (his willingness to serve) to the corporation's purpose (maximization of profit) [Bennett (1933)]. Understanding intra-organizational communication necessitates that the corporation be viewed as a complex, dynamic network structuring and sustaining capitalist individuality as an essential means for the realization of its purpose (profit maximization). Management systems analysts portray the corporation as a living thinking system and emphasize organizational learning [Gravis (1993)]. Interaction between Chaos theorists and some system management thinkers has led to the realization that environmental feedback is key to organization learning. Systems theory, therefore, underlines the importance of viewing the corporation as part of a complex whole (capitalist order) [Gravis (1993): p. 87-89].

Several attempts have been made by management theorists to combine different elements of the Scientific Management, HRM and the Systems approaches. The most widespread of these is the 'Contingency approach' which emphasizes that there are not universally applicable principles for relating diversity to singularity. Different situations require different approaches - scientific management may be more suitable for increasing efficiency in a steel mill and HRM approach may be a useful means for enhancing productivity in a corporation which mainly employs copy writers [Shetly (1974)]. As a whole, Management theory emphasizes that capitalist individuality is not spontaneously produced in the market. It has to be structured and sustained within corporation hierarchies (which are extra market phenomenon) through interaction between the corporation and its stakeholders and through the regulation of the corporation by the capitalist states. Management theory therefore provides a much more realistic analysis of how capitalist order functions than does economics. However economics continues to provide the ideal types - the optimizing models - on the basis of which actually existing markets can be evaluated in terms of their conformance with capitalist ideology. Management science may therefore be viewed as a practice for moving capitalist realities towards capitalist ideals. 


\section{FUNCTIONALITY OF ECONOMICS AND MANAGEMENT DISCOURSE IN TWENTY FIRST CENTURY CAPITALISM}

During 2007-2009, global capitalist order has been going through a major financial crisis - the worst since the years of the Great Depression. But there are far fewer signs of resistance and revolt than there were four decades ago when following the upheavals of 1968, there was a surge of serious militancy in France, Italy, Britain and several other west European countries. The United States was in the grip of a powerful anti-war movement and Keynesianism was thoroughly discredited throughout the Western world.

But capitalist order — both at the national and the global level-emerged strengthened from the crises of both the 1930s and in the 1970s. Boltanski and Chiapello (2008) attribute some of this triumph to management discourse. It was the ability of management discourse to incorporate many of the critiques raised against capitalist practices, especially at the level of the shop floor which enabled management to defuse worker militancy and make workplace discipline and organization both acceptable and attractive to a large majority of workers. Unions were defeated. Man hours lost due to industrial action plummeted. Industrial relations and collective bargaining mechanisms lost their functionality and the distinction between 'boss' and 'operator' within the corporation became increasingly blurred.

Boltanski and Chiapello (2008) undertake an exhaustive survey of French Management literature during the period 1991-2001 to show that this literature provided insights which enabled management to win worker support for "re-appropriating" the critique of the 1960s within capitalist order. This was similar to the role of Keynesianism played after the crises of the 1930s. This re-appropriation of the 1970s critique enabled capitalism to articulate a new "spirit" providing formerly antagonistic workers with reasons for abandoning antagonism and participating enthusiastically in capital accumulation. This "new spirit" demonstrates the justice of capitalist order and provides "tests" demonstrating that this justice characterizes capitalist transactions. The "new spirit" successfully substituted the "tests" of collective bargaining and career advancement mechanism by tests of mobility, versatility and project switching opportunities.

The management literature of the 1990s succeeded in inducing the leading French enterprises to become "(l)ean, working as network, with a multitude of participants, organizing work in the form of projects intent on customer satisfaction (and) mobilization of workers (on the bases of) their leader's vision. Co-organizational principles like just in time, total quality, autonomous production teams and locus of tools to implement them (became widely) acceptable" (Boltanski and Chiapello, 2007: p. 73-74).

In the leading French firms "Taylorist" production systems gave way to more consensual orderings where firms adopted networking, dismantled rigid management 
hierarchies and structured management worker relationship to promote autonomy. This enabled management "to reassert control on their own particular batch to get these subordinates back to work, increase their margin of maneuver and to restore profits" (p. 501).

The new work culture was characterized by "autonomy spontaneity, delayering of hierarchies, multitasking, openness to others, sensitivity to differences, informality and interpersonal contacts" (p. 97). This neutralized what Boltanski and Chiapello describe as "the artistic critique" expressing the resentment, the inauthenticity of capitalist life-experiences, the subjugation of individual creativity brought about by standardization and commodification of labor process under Fordism. Management succeeded in making work more rewarding in the "artistic" side in the sense that it enhanced opportunities for the expansion of individual autonomy and creativity and this blurred and deferred the social critique which was aimed at inequitable distribution of wealth and power and rising poverty. "Exploitation" and social inequalities became more acceptable to workers as work process autonomy and flexibility was enhanced. The struggle for state governance of markets, social security and worker representation lost its edge.

Employees used management discourse to disarm worker militants and work process reorganization proved more effective than layoffs and lock outs in de-constructing capitalist resistance. The Manager "became a democratic leader (rather) than a dictator; authoritarian management was replaced with the semi-autonomous work group" (p.168) Centralized bureaucratic structures gave way to "decentralization meritocracy and management by objectives" (p. 65).

The emphasis on individualization, creativity and mobility "served as a lever for decoupling capitalism from the state (p. 504). Bourdiou, Derrida and Deluze delegitimated the interventionist state Trade Union struggles focused on capturing state apparatuses for contesting management authority thus lost popular support. Management discourses have thus proved their utility in enabling capitalist order to relegitemate itself and disarm some of its leading critics in the third quarter of the twentieth century.

During 1987-2009 there have been three major down turns in global capitalist growth; 1987-91, 2000-2003 and 2007 to the present. In none of these was capitalist hegemony seriously challenged by the national labor movements in the metropolitan capitalist countries (except perhaps in France in 1995 and 2005 but these were not enterprise specific challenges disputing management authority. They were movements against roll back of the macroeconomic commitments of the social welfare state, which is not management discourse's primary concern). The "globalization from below" movement which emerged in 1999 soon became something of a garland, rather, a banner. The annual festivals of the World Social Forum (WSF) pose no serious threat to capitalist order and the multinational organization of production and finance. 
A less convincing case can be made for the continued (capitalist) functionality of economics discourse. As we have seen above economics discourse is concerned with providing ideal types against which actually existing behavior can be measured and for the formulation of macroeconomic and market regulatory policies to move actually existing capitalist transaction forms towards ideal types derived from capitalist rationality. Sraffa and the Post Keynesians have identified the inconsistencies and incoherence embedded in neoclassical micro and "macroeconomics" discourses conceptualizing ideally rational forms of market behavior and state market governance structures. While Sraffa (though not all Sraffians) seems to argue that capitalism's inherent contradictions are insurmountable and capitalist collapse is therefore inevitable, neither Marxists nor most post Keynesians share this view. Both Marxists and post Keynesians seek to present a truer and more authentic description of capitalism identifying space within the system for policy interventions what enable the system to achieve the objective of unending capital accumulated through the maximization of utility/profit. An eclectic incorporation of Post Keynesian and Post Marxist themes within neoclassical discourse remains possible - and indeed necessary during periods of capitalist crisis — and can lead to the reformulation of the ideal types of market transactions and state market relationshipsas shown by the adoption of Keynesianism in the 1950s. Incorporating elements of Sraffa's theory in this way, however, seems impossible.

Institutional economics and related complexity analysis may also have the potential to articulate a more coherent understanding of capitalist reality. Meso (i.e. institutional structure) responses to disequilibria and institutional economics' understanding of the capitalist market as a dynamic system incorporating uncertainty in its formal analysis makes it useful for understanding how innovation and entrepreneurship is being institutionalized in capitalist order. Some Intuitionalists have also developed framework for showing that despite its evolutionary characteristics the market system possesses inherent characteristics for assimilating crisis situation in its normal functioning process. They can provide a much needed discourse for understanding capitalism's resilience to systemic shocks [Hodgeson (1999)].

The evolutionary variants of Institutional Economics may provide a more profound and better nuanced explanation of capitalist state capacities and policies than mainstream economics. Based on orthodox microeconomic foundations, Institutional / Evolutionary Economics is also functional in that it allows the analysts to methodically relax 'ceteris paribus' assumptions of standard economic theory to develop a better understanding of the functioning of capitalist markets. This is also true of Behavioral Economics, which is also functional and realistic, adding depth to microeconomic analysis [Fudenberg (2006) and Barnett (2000)].

Complexity theory applications to the study of market functioning can also deepen economic analysis. These applications (especially those on the basis of Chaos theory) identify non linear relationships among elements within the market system and 
investigate the capability of the market system to self-organize [Rosser (1999)]. Chaos theory applications in the physical sciences show that often behind apparently chaotic behavior there is an organizing force which Lorenz called "a strange attractor" [Keen (2004), chap 12]. Complexity theorists working on market systems sometimes claim that behind apparent persistence of disequilibrating price and output configuration there exist similar "strange attractors" which produce business cycles but (may) also ensure that the cyclical behavior of the capitalist market system is self corrective and self sustaining [Nightingale (1999)]. If Complexity analysis can identify "strange attractors" it will make a major contribution to the understanding of capitalist market order.

Economics discourse thus remains indispensable - and as yet untranscendedas an instrument for articulating capitalist rationality no matter however incoherently it attempts to do this. The affectivity of economics discourse is limited in two ways (a) First as Sraffa shows that capitalism is a conflict ridden, chaotic system generating discord not harmony and its maxims are therefore not universalizable (b) and secondly economics cannot prevent the transcendence of capitalist rationalization, the individual and social rejection of capital accumulation (utility/profit maximization) as an end in itself. Economics cannot persuade me to adopt the capitalist way of life and if I reject capitalist order economics has nothing to say to me or about me.

Management theory also faces two major challenges in the twenty first century. First, as Lash and Urry pointed out twenty years ago (1988) that capitalist order is unraveling. The capitalist state is "withering away" and the capitalist life world ("civil society') is inundated with meaninglessness. Boltanski and Chappiallo (2008) in their masterly review of French post-modernist management theory have shown how difficult is to maintain market order in these circumstances. Post modernist Management theory has responded by advocating social responsibilisation of business and the delayering of organizational hierarchies so that almost everyone can "do his/her own thing". But delegitimization of state regulation (i.e. regulation by the democratically sanctioned representative of capital in general) and dismantling of firm and market commercial structures compatible with capitalism's supreme singularity — profit / utility maximization? Boltanski thinks not but as dear, departed Zhou En Lai said "perhaps it is too early to tell".

Secondly, Management theory's American genesis limits its applicability to un-American societies - societies which are not and do not wish to become America. Here Management is an alien import thrust upon Kipling's "new caught sullen people, half devil and half child" by imperialist armies. Can Management be un-Americanized and embedded in un-American societies? John Grey (1999) argues that while Russia and most of Latin America have failed to do this, Germany, Japan, South Korea and China have succeeded in building distinctly national capitalisms involving among other things an indigenization of Management. 
What is happening in Pakistan? Pakistan's specific management literature remains woefully sparse. We teach American text books and assume the inevitability of the Americanization of Pakistan. The time has come for challenging these assumptions and for developing an objective analytical framework for understanding organizational processes in Pakistani society and economy.

\section{REFERENCES}

Agleitta M (2000), A Theory of Capitalist Accumulation: The US Experience, London Verso

Ansari J and Z Arshad (2006), Business Ethics in Pakistan, Karachi

RBCAnsari J.A and Khan R (1999), "Social Democratic Reform Proposals and the Future of Capitalism", Pakistan Development Review, vol 38 (4): p. 1211-1232

Baran P and S Sweezy P (1953), Monopoly Capital, New York Monthly Review Press

Barnett E (1933), The Functions of the Executive, Cambridge Mass Harvard University Press

Barnett WA (2000), Commerce, Complexity and Evolution, New York Cambridge University Press

Bhardawaj K and Schofeld (ed) (1990), Essays On Pierro Sraffa; Critical Perspectives On the Revival of Classical Theory, London Unwin Hyma

Boltanski L and Chiapello (2008), The New Spirit of Capitalism, London Verso

Bose A (1980), Marx on Exploration and Inequality, Delhi Oxford University Press

Callinicos A (1999), Social Theory, Cambridge Polity

Epstien L and Stanly E (1989) "Substitution, Risk Aversion and the Temporal Behavior of Consumption and Asset Returns: A Theoretical Framework", Econometrica, vol. 57 (4): p. 937-69

Fayol F (1949), General and Industrial Management, London Pitman

Feigenbaum A (1951), Total Quality Control, New York Basic Books

Foucault M (1988), "The ethics of care for the self as a practice of freedom" in J Benaver and D Rammusen (ed) The Final Foucault, Boston M.I.T Press

108 
Freeman A and Carchedi G (1996), Marx and Non Equilibrium Economics, Cheltenham Edward Elgar

Fudenberg D (2006), “Advancing Beyond Behavioral Economics”, Journal of Economic Literature, vol. XLIY Sept 694-711

Gravis D (1993), “Building a Learning Organization”, Harvard Business Review, vol. 71 (July-Aug): p. 78-91

Gray J. (1999), The False Dawn, London Plato

Hayek F (1988), The Final Conceit, London Routledge

Hicks J (1956), Value and Capital, London ECBS

Hilferding R (1969), Finance Capital, New Haven Yale University Press

Hobsbaw M E (1995), The Short Twentieth Century, Harmondsworth Allen Lane

Hodgson GM (1999), Evolution and Institutions: On Evolutionary Economics and the Evolution of Economics, Cheltenham Edward Elgar

Jaran J (1993) Made In USA: A Renaissance in Quality”, Harvard Business Review, vol. 71 (July-Aug): p. 42-50

Kass F (2003), Organization and Management: A Systems Approach, New York Harper

Keen S (2004), Debunking Economics, London Zed

Keynes J.M (1936), The General Theory of Employment, Interest and Money, London Macmillan

Lash S and Urry J (1988), Unorganized Capitalism, London Polity

Lavoie M (1994), “A Post Keynesian approach to consumer choice”, Journal of Post Keynesian Economics, vol. 16 (3): p. 539-567

Littler C (1983), "Deskilling and changing structures of control" in S. Wood (ed), The Degradation of work, London Hutchison: p. 141-166

Mahun S (1994), Debates on Value Theory, New York St Martins Press

Mayo (1993), The Human Problems of An Industrial Civilization, Cambridge Mass MIT Press 
Merzaros I (1995), Beyond Capital, London Merlin

Metcalf H and L Ururick (1942), Dynamic Administration: The Collected Papers of Mary Parker Follet, New York Harper

Nightingale J (1999), "Universal Darwinism and Social research: the case of economics" in Barnett (1999): p. 63-101

Rosser J.B (1999). "On the complexities of complex economic dynamics” Economic Perspectives, vol. 13 (4): p. 169-192

Sraffa P (1960), Production of Commodities by Means of Commodities, London Cambridge University Press

Sraffa P (1926), “The Law of Return under Competitive Conditions”, Economic Journal, vol. 40 (4): p. 538-550

Schumpeter J (1949), A History of Economic Analysis, New York Macmillan

Shetly Y.V (1974), “Contingency Management: Current Perspectives for Managing Organizations", Management International Review, vol. 14 (4): p. 23-42

Smith A (1972), The Wealth of Nations, London Allen and Unwin

Tawney R (1949), Religion and the Rise of Capitalism, Harmondsworth Penguin

Taylor E.V. (1947), Scientific Management, New York Harper and Row

Weber M (1966), Economy and Society, London Lawrence Wisehart

Wilde L (1989), Marx and Contradiction, Aldershot Avebury

A healthful hunger for a great idea is the beauty and blessedness of life.

110 